\title{
Oceanography
}

CITATION

McGlathery, K.J., M.A. Reidenbach, P. D’Odorico, S. Fagherazzi, M.L. Pace, and J.H. Porter.

2013. Nonlinear dynamics and alternative stable states in shallow coastal systems.

Oceanography 26(3):220-231, http://dx.doi.org/10.5670/oceanog.2013.66.

DOI

http://dx.doi.org/10.5670/oceanog.2013.66

COPYRIGHT

This article has been published in Oceanography, Volume 26, Number 3, a quarterly journal of The Oceanography Society. Copyright 2013 by The Oceanography Society. All rights reserved.

USAGE

Permission is granted to copy this article for use in teaching and research. Republication, systematic reproduction, or collective redistribution of any portion of this article by photocopy machine, reposting, or other means is permitted only with the approval of The Oceanography Society. Send all correspondence to: info@tos.org or The Oceanography Society, PO Box 1931, Rockville, MD 20849-1931, USA. 


\section{Nonlinear Dynamics and Alternative Stable States in Shallow Coastal Systems}

BY KAREN J. MCGLATHERY, MATTHEW A. REIDENBACH, PAOLO D'ODORICO, SERGIO FAGHERAZZI, MICHAEL L. PACE, AND JOHN H. PORTER

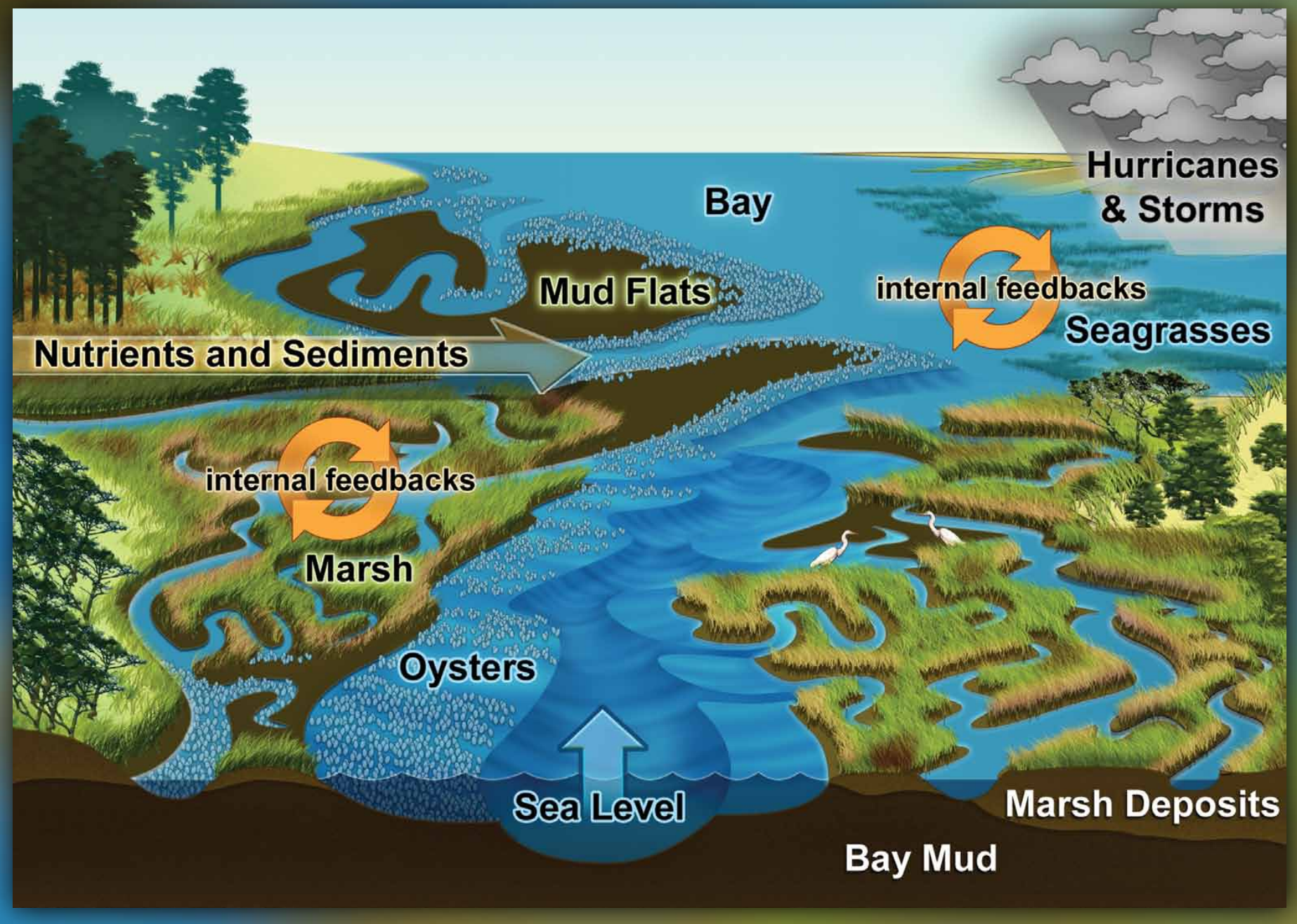

Figure 1. A conceptual framework for the study of interactions between the dynamics of marshes and shallow bays that are controlled by external drivers - sea level rise, storms, and sediment and nutrient supplies—and internal feedbacks. These feedbacks can lead to the emergence of thresholds, hysteresis, and alternative stable states, and induce an overall nonlinear response of shallow coastal environments to large-scale external drivers. Understanding potential state transitions and how the occurrence of a regime shift in one subsystem propagates to others is a critical frontier in forecasting the long-term evolution of coastal systems. 
ABSTRACT. The dynamics of shallow-water coastal environments are controlled by external drivers - sea level rise, storms, and sediment and nutrient supplies-and by internal feedbacks. Interactions of biotic processes (vegetation growth, trophic dynamics) and abiotic drivers can lead to nonlinear responses to changing conditions and to the emergence of thresholds, hysteresis, and alternative stable states. We develop a conceptual framework for studying interactions between the dynamics of marshes and habitats in shallow coastal bays with unconsolidated sediments (seagrass, oyster reefs). Using examples primarily from the Virginia Coast Reserve Long Term Ecological Research site, we show that in the subtidal part of the landscape, two alternative stable states can exist-one dominated by seagrass up to a certain depth that represents a tipping point to the second, unvegetated stable state. The depth limit of the seagrass stable state is influenced by (1) the positive feedback of vegetation on reducing sediment suspension and improving the light environment for growth, (2) climate (e.g., temperature), and (3) water quality. Two stable states are also present in intertidal areas, with salt marshes lying above mean sea level and tidal flats below mean sea level. State transitions are driven by sediment availability, sea level rise, the relative strength of wind waves with respect to tidal currents, and the biotic feedback of vegetation on sediment stabilization and accretion. State-change dynamics in one system may propagate to adjacent systems, and this coupling may influence the landscape-scale response to environmental change. Seagrass meadows and oyster reefs affect adjacent marshes both positively (wave attenuation) and negatively (reduced sediment supply), and marsh-edge erosion could negatively influence the light environment for seagrass growth. Forecasting the resilience of coastal ecosystems and the landscape-scale response to environmental change in the next century requires an understanding of nonlinear dynamics, including the possibility of multiple stable states, the coupled evolution of adjacent systems, and potential early warning signs of thresholds of change.

\section{INTRODUCTION}

Understanding the processes that cause nonlinear changes in coastal marine ecosystems is critical, given growing anthropogenic pressures. In this context, some of the best examples of nonlinear ecological changes and their underlying causes have come from marine studies, including research at coastal sites in the Long Term Ecological Research (LTER) network (Box 1). A key feature of this research is integrating physical, chemical, and biotic processes into better understanding the forces that are driving ecological dynamics. Predicting future scenarios and adapting to changing environmental conditions will require ongoing research on how systems respond to trends in external forces interacting with internal processes. Here, we consider the case of shallow-water coastal environments with unconsolidated sediments. The dynamics of these environments are controlled by external drivers-sea level rise, storms, and sediment and nutrient supply_-and by internal feedbacks. Although it is well established that the interplay between sea level rise and sediment supply controls the large-scale features of the softsediment coastal landscape, the role of feedbacks resulting from the interaction between biotic processes (vegetation growth) and abiotic drivers (e.g., waves, tides, storm surges, sediment and nutrient supplies) has only recently been recognized (Figure 1; Marani et al., 2007; Carr et al., 2012a,b; Fagherazzi et al., 2012a,b; Mariotti and Fagherazzi, 2012). These feedbacks can lead to the emergence of thresholds, hysteresis, and alternative stable states (e.g., Walker and Salt, 2006), and induce a nonlinear response to large-scale external drivers (Box 2). In addition, interacting drivers can create a landscape that changes rapidly at any specific location, but is remarkably unchanging in aggregate. For example, during a 28 -year period, $>42 \%$ of island upland locations of the Virginia Coast Reserve (VCR) LTER landscape changed to either marsh or water, but the aggregate amount of upland changed by less than $6 \%$ as new upland was deposited to counterbalance the loss of eroded or flooded uplands (Figure 2; Porter, 2007).

For shallow-water soft-sediment coastal systems, positive feedbacks and possible state changes are typically associated with the ability of vegetation to improve its own habitat by modifying the physical environment. In the presence of two stable configurations, even small changes in external drivers may cause an abrupt shift of the system from one state to another. For instance, an initial loss of vegetation in marshes or shallow coastal bays may be enhanced by interactions with the physical environment (e.g., increase in hydroperiod or decrease in light) that cause further changes in canopy cover and eventually lead the system into a different state. The transition can be highly irreversible because the "new" state is also stable, and other factors must come into play 
BOX 1. ECOSYSTEM REGIME SHIFTS AND EARLY WARNINGS: EVIDENCE FROM MARINE LTER SITES

Ecosystem regime shifts are massive changes that occur abruptly and move systems to new states that may not be readily reversible (Scheffer et al., 2001; Carpenter, 2003; Walker and Meyers, 2004). These changes involve critical transitions characterized by the crossing of thresholds (Scheffer, 2009). Although these changes will be evident in ecosystems throughout the world, coastal marine ecosystems are particularly vulnerable because of the combined effects of climate change, sea level rise, and intensification of human use.

Examples of regime shifts and nonlinear dynamics have been described in Long Term Ecological Research (LTER) marine sites in addition to those discussed here for the Virginia Coast Reserve LTER. For example, at the Santa Barbara Coastal LTER, there are shifts in rocky-reef structure from algal to sea cucumber dominated communities and from kelp forests to urchin dominated benthic barrens (Harrold and Reed, 1985; Rassweiler et al., 2010). At the Florida Coastal Everglades LTER site, nutrient enrichment and increases in salinity are associated with loss of seagrass and a shift to phytoplankton dominance in Florida Bay, but these changes are embedded within a series of hydrographic, physical, and climatic changes that have influenced long-term ecosystem dynamics (Briceño and Boyer, 2010; Wachnicka et al., 2013). The decline of Adélie penguins at the Palmer LTER in Antarctica has led to a cascade of changes where a threshold appears to have been crossed (Bestelmeyer et al., 2011). Other shifts such as salt marsh diebacks at the Georgia Coastal Ecosystems LTER (Ogburn and Alber, 2006; Angelini and Silliman, 2012) and the collapse of marsh creek banks under nutrient loading at the Plum Island Ecosystems LTER, Massachusetts (Deegan et al., 2012), may or may not reflect regime shift dynamics, but nonetheless are stark and unexpected system alterations. Although alternate state dynamics are often associated with nonlinear processes that move systems among alternate attractors, demonstrating nonlinear dynamics is often difficult (Schröder et al., 2005). Further, Di Lorenzo and Ohman (2013) provide evidence for marine plankton at the California Current Ecosystem LTER that regime-shift-like dynamics are well modeled by linear combinations of environmental and climatic forcing. Thus, strong apparent transitions should not always be interpreted as nonlinear dynamics resulting in alternative states.

An interesting feature of regime shifts is that pending changes may be detectable in advance (Scheffer et al., 2009). Critical slowing down is evident in model systems undergoing certain types of critical transitions (e.g., fold bifurcations). There is a loss of resilience, and systems exhibit greater and greater departures from a baseline (Van Nes and Scheffer, 2007). Consequently, there are early warning indicators (EWI) for such cases in time series and spatial patterns that foreshadow the regime shift. Most of these indicators are based on common statistics, for example, the variance or autocorrelation of a time series variable across a sequence of time windows. Carr et al. (2012b) identified leading indicators of seagrass meadows in the VCR LTER approaching a critical bifurcation point using future scenario modeling on decadal time scales. For variables measured at high frequency relative to the time scale of regime shifts, these indicators provide a means of anticipating and possibly forestalling unwanted changes (Biggs et al., 2009; Contamin and Ellison, 2009). Empirical tests of EWI are based mainly on laboratory systems (Drake and Griffin, 2010; Dai et al., 2012; Veraart et al., 2012) or retrospective analyses (Dakos et al., 2009; Bestelmeyer et al., 2011; Lindegren et al., 2012). However, a recent whole-lake manipulation designed to cause a regime shift also provides evidence of EWI about a year prior to the completion of the system change (Carpenter et al., 2011; Seekell et al., 2012; Pace et al., 2013). Thus, it may be feasible to detect pending regime shifts in ecosystems using increasingly available high-frequency data from in situ instruments as well as from remote sensing. to destabilize the system before it can revert back to its initial configuration. Thus, when considered separately, both marshes and shallow coastal bays may exhibit bistable dynamics induced by (positive) vegetation feedbacks. Marshes and bays have only limited resilience: if disturbed beyond a critical level, they shift to a qualitatively different state.

In the VCR LTER and similar coastal bay systems, the eastern oyster Crassostrea virginica forms a threedimensional, complex reef structure primarily in intertidal regions that fringe mainland marshes and tidal-channel banks. Disease and poor management have contributed to widespread loss of oysters along the East Coast of the United States (Rotschild et al., 1994; Kemp et al., 2005), resulting in a state change from intertidal oyster reef habitat to mudflats (Rotschild et al., 1994; McCormick-Ray, 2005). Once this transition occurs, mudflats often stay in a stable equilibrium. A challenge for oyster

Karen J. McGlathery (kjm4k@virginia. edu) is Professor, Department of Environmental Sciences, University of Virginia, Charlottesville, VA, USA.

Matthew A. Reidenbach is Associate Professor, Department of Environmental Sciences, University of Virginia, Charlottesville, VA, USA. Paolo D'Odorico is Professor, Department of Environmental Sciences, University of Virginia, Charlottesville, VA, USA. Sergio Fagherazzi is Associate Professor, Department of Earth and Environment, Boston University, Boston, MA, USA. Michael L. Pace is Professor, Department of Environmental Sciences, University of Virginia, Charlottesville, VA, USA. John H. Porter is Research Associate Professor, Department of Environmental Sciences, University of Virginia, Charlottesville, VA, USA. 
recovery efforts is to promote successful transport and settlement of oyster larvae, and ultimately metamorphosis and growth to adult oysters, to create new reef habitat (Coen and Luckenbach, 2000; Levin, 2006).

In this paper, we develop a conceptual framework for studying interactions between marsh and shallow-bay habitat dynamics (seagrass, oyster reefs) in systems with unconsolidated sediments, in large part based on research at the VCR LTER site. We investigate how the occurrence of an ecosystem state change in one of these units propagates to the others and potentially induces a state transition in the large-scale evolution of the coastal environment. For example, a decrease in seagrass density-likely sustained by feedback from sediment resuspension and light availabilityintensifies the supply of suspended sediment to adjacent marshes, thereby favoring their accretion. At the same time, the decline in seagrass cover reduces sediment trapping and enhances sediment suspension and bed scouring in shallow bays, potentially reducing the sediment available for marsh accretion. Oyster reefs adjacent to marshes similarly impact marsh-edge erosion and vertical accretion by reducing sediment availability and dissipating wave energy. It is still unclear, however, how the interaction between marshes and coastal bays affects the vulnerability of these coastal environments to sea level rise. Hence, understanding potential state transitions

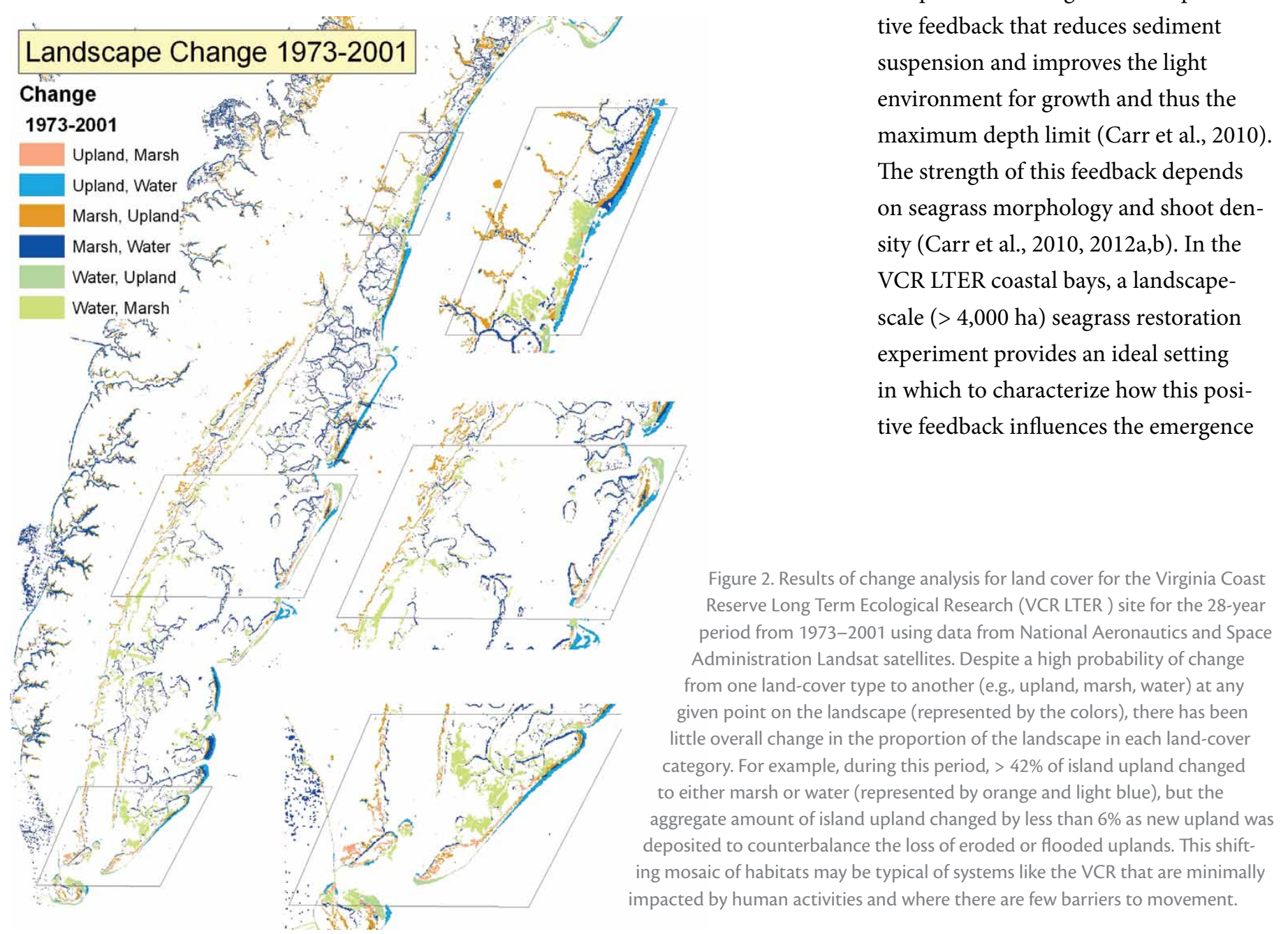


BOX 2. TERMS AND DEFINITIONS

\section{ASSOCIATED WITH ALTERNATIVE STABLE}

STATES AND NONLINEAR DYNAMICS

ALTERNATIVE STABLE STATES: Dramatic changes in ecosystems may lead to fundamentally different conditions referred to as states (Scheffer, 2009). An example is a bare sea bottom that changes to a seagrass-covered bottom. The two conditions represent distinct states or alternative states in terms of biological, chemical, and/or physical conditions that cascade to affect trophic dynamics. Furthermore, states tend to be sustained in their current condition by stabilizing positive feedbacks. For example, seagrasses stabilize sediment, thereby limiting its resuspension, which promotes light penetration and seagrass growth (van Katwijk et al., 2009). This feedback of seagrass on sediment stabilizes the seagrass state. When the bottom of a shallow-water lagoon shifts between two conditions, such as the example of bare versus seagrass-covered, the system exhibits bistable dynamics. In contrast, multiple stable state conditions would be exhibited if a system changed among three or more distinction conditions (May, 1977). Multiple stable state dynamics are difficult to detect (Peterson, 1984), but rocky shores in the Gulf of Maine provide an example (Petraitis et al., 2009; see also discussion of possible multiple stable state conditions in text).

NONLINEAR DYNAMICS: The description of nonlinear dynamics involves a number of terms that are particularly useful in the context of the state changes discussed. Important terms used in this paper are driver, positive feedbacks, crossing of thresholds, resilience, and hysteresis. Here, we give brief definitions and examples of these terms. Drivers are external or internal forces that determine the response of a system or a system component. Salt marsh grass production may increase with increasing nitrogen inputs and the response may be linear over a specific range of inputs. However, continuous increases or long-term impacts may cause a nonlinear change in a driver-response relationship as in the case of salt marsh collapse under experimental nutrient fertilization (Deegan et al., 2012; see Box 1). Positive feedbacks are processes that may promote the stability of alternative states (Scheffer et al., 2001). For example, past declines of sea otter populations in coastal systems led to positive feedbacks on sea urchins such that population growth was unregulated by predators and outbreaks of sea urchins decimated coastal kelp forests (Steneck et al., 2002). One result of positive feedbacks may be that systems will cross a threshold that leads to irreversible or difficult to reverse change. Thresholds are rarely evident until after they are crossed and a system has shifted (Groffman et al., 2006). Excessive fishing mortality may cause thresholdlike collapses in targeted species (e.g., Hutchings, 1996). Systems also resist change and, when mildly or moderately disturbed, return to prior conditions. The degree of change required to push a system to a new state as opposed to restabilizing in the old condition is a measure of resilience (Carpenter, 2003). Resilient systems have many mechanisms that promote stability in the current state and limit shifts to a new state. Finally, hysteresis refers to distinctly different system trajectories under the increase and decline in a driver. Primary production in coastal systems is often sensitive to external inputs of nitrogen. Management that leads to declines in external nutrient inputs will typically cause a decline in producer production and biomass. However, the trajectories of the system in the forward (nutrient increase) and reverse (nutrient decline) directions are different. Examples based on long-term data on nutrient loading and phytoplankton biomass from coastal systems exhibit this hysteresis as well as incomplete recovery to former baseline conditions (Duarte et al., 2009). of alternative stable states (Carr et al., 2010; Hansen and Reidenbach, 2012; McGlathery et al., 2012).

Seagrass canopies slow flow and shelter underlying sediment, reducing its susceptibility to resuspension and enhancing deposition of fine sediment, which feeds back to increase the transparency of the water column (Folkard 2005; Hansen and Reidenbach, 2013). Seagrass decline, either from disturbance or from chronic stress of nutrient loading or high temperatures, can cause these positive feedbacks to rapidly shift a system from a state with clear water and a seagrass-covered bottom to an alternative state with turbid water and no seagrass cover (McGlathery et al., 2007; van der Heide et al., 2007; Carr et al., 2010, 2012a,b).

The positive feedback of seagrass on water clarity is the basis for a hydrodynamic model of vegetation-sedimentwater flow interactions coupled to a seagrass growth model developed at the VCR LTER that describes alternative stable state dynamics (Figure 3; Carr et al., 2010). The hydrodynamic model simulates the one-dimensional dynamics (in the vertical direction) of sediment settling within the water column. It accounts for the effect of seagrass vegetation on waves and currents and the resulting shear stress at the sediment surface. The seagrass growth model allocates growing and senescing aboveground biomass into structural components (e.g., leaves and rigid base of the shoot), and accounts for translocation of carbon between above- and belowground biomass and for shoot recruitment and mortality (Verhagen and Nienhuis, 1983; Zharova et al., 2001; Carr et al., 2010).

Analysis of long-term data acquired and experiments conducted in the 
VCR LTER coastal bays agrees remarkably well with the model predictions.

These data indicate a maximum depth limit for stable seagrass meadows determined by light availability and a minimum depth limit set by high summertime temperatures (McGlathery et al., 2012; Reynolds et al., 2012). Modeling of future scenarios shows that climate warming is more important than sea level rise in limiting the productivity of seagrass meadows and driving state change (Carr et al., 2012a,b). Seagrass meadows have limited resilience on decadal time scales. In particular, hightemperature events that increase both respiration and light requirements result in a shift of stable seagrass meadows to shallower depths (Carr et al., 2012a,b; McGlathery et al., 2012). At the margins of the range of suitable water depths, seagrasses may undergo abrupt transitions and catastrophically shift to the alternative state of bare sediment. Once this transition occurs, water movement scours the seabed sediment, resulting in an increase in water depth and a decline in light availability. These processes enhance the strength and irreversibility of the causes and effects of seagrass loss.

\section{Marsh/Mudflat}

Alternative stable states also exist between tidal flats and salt marshes in intertidal and subtidal areas (Figure 4; Fagherazzi et al., 2006; Marani et al., 2007, 2010). Tidal flats are maintained below mean sea level by the action of wind waves, which erode bottom sediment and prevent accretion (Fagherazzi and Wiberg, 2009). However, there is a critical water depth at which wave bottom shear stresses are maximum. Above this depth, wind waves cannot prevent shoaling and the tidal flat is free to accrete, morphing into a salt marsh
(Fagherazzi et al., 2006). Two stable states are therefore present in intertidal areas, with salt marshes lying above mean sea level and tidal flats below mean sea level (Fagherazzi et al., 2006). Very few intertidal areas lie at intermediate elevations, and the system can shift from one state to the other in a short time (Fagherazzi et al., 2007). In particular, fast oscillations in tidal flat elevation represent an indicator of possible state shift (Fagherazzi et al., 2007). Biotic processes have an important role in stabilizing salt marshes and tidal flats (Marani et al., 2007). The feedbacks between topography and marsh vegetation primary productivity dictate marsh equilibrium (Morris et al., 2002; Marani et al., 2007). Microalgae can stabilize mudflats by binding cohesive sediments with organic biofilms (Paterson, 1989; Marani et al., 2010). Waves and tidal currents also affect the presence of biofilms on mudflat substrates, driving the total biofilm biomass toward either zero or fully developed (Mariotti and Fagherazzi, 2012) and favoring spatial patchiness that can be used as an indicator of an impending regime shift (Weerman et al., 2012). Thus, biota both change the equilibrium states of marshes and mudflats and promote new stable points. For example, Marani et al. (2007) show that microalgae are critical for the presence of intertidal flats in the Venice lagoon, Italy, and that without their stabilizing effect, the bottom could only exist in a subtidal state. Three equilibrium states can therefore be present: subtidal, tidal flat, and salt marsh, with biological factors largely

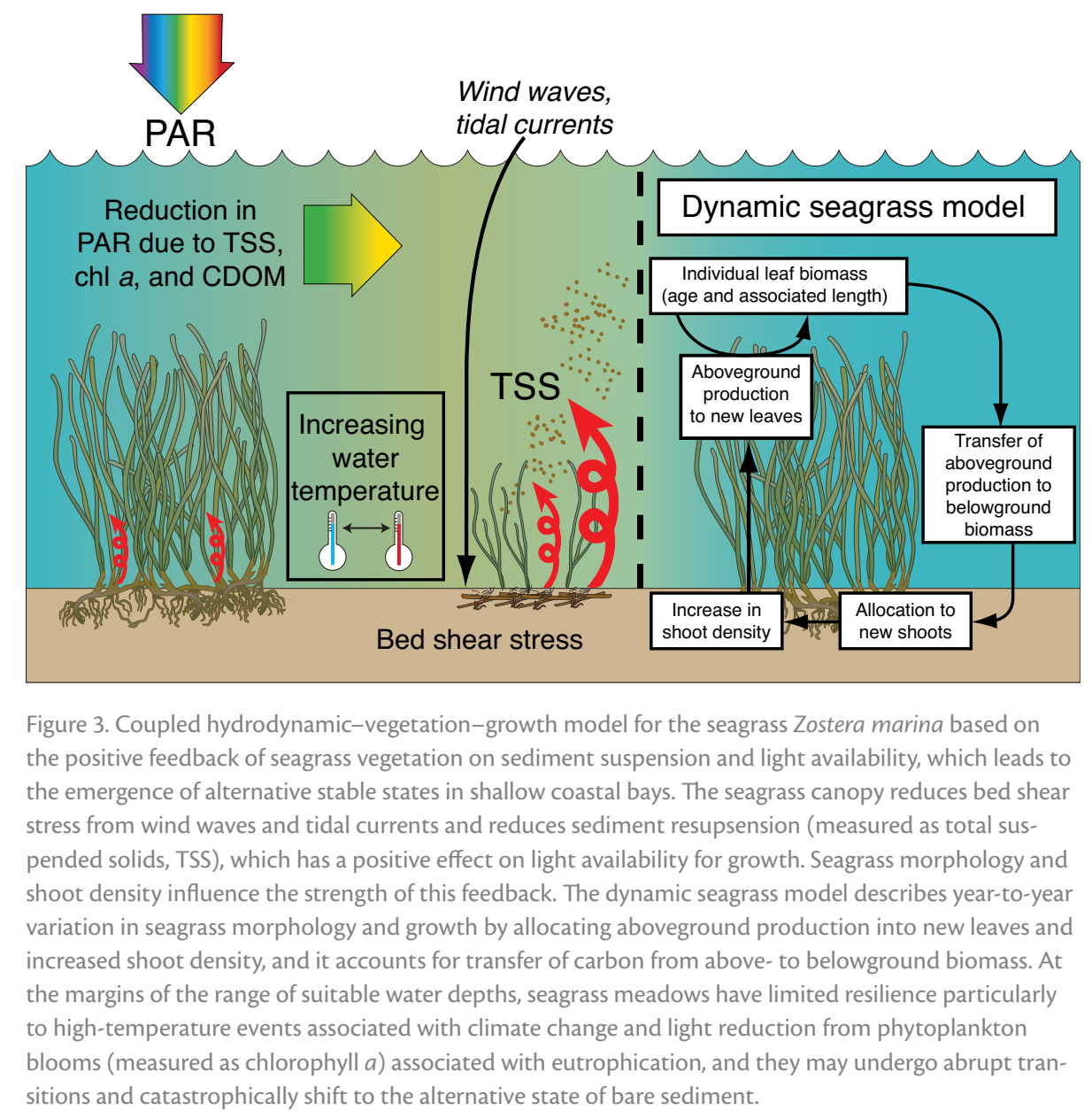




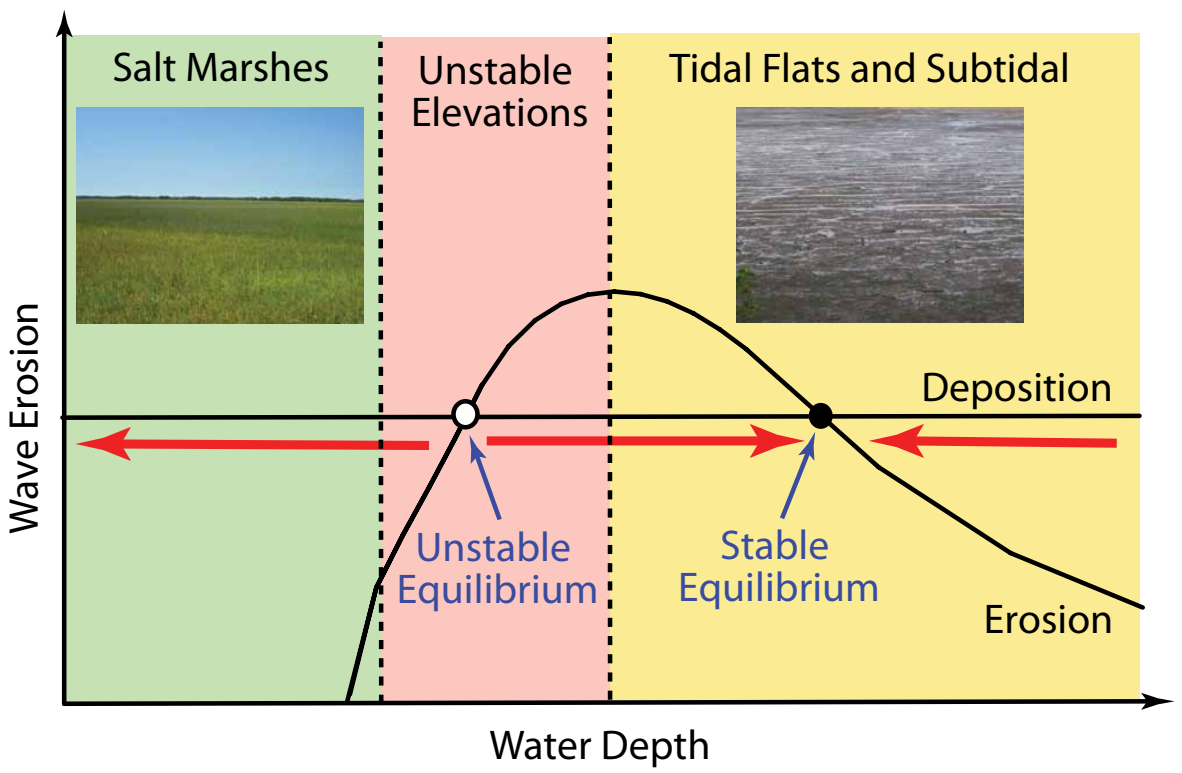

Figure 4. Wave erosion as a function of water depth in tidal flats. Equilibrium is attained at two points when sediment deposition equals erosion. However, one of the points is unstable, and small variations in elevation are not recovered by the system.

driving the last two.

Hysteresis occurs when the effect of vegetation is accounted for in the dynamics of the salt-marsh platform in the presence of different equilibrium elevations for a given rate of sea level rise (Marani et al., 2010). The current system state (i.e., marsh elevation) is therefore not only a function of external drivers (sea level rise, sediment input) but also of the morphodynamic history of the system and biotic feedbacks.

A similar nonlinear dynamic is also valid for tidal flat channels. Tidal currents that concentrate flow in selected directions cause channel incision. In contrast, wind waves flatten the landscape and prevent channel formation (Mariotti and Fagherazzi, 2013). In the absence of waves and with available sediment supply, the intertidal area evolves into salt marshes dissected by tidal channels. When waves are very energetic, a low, uniform tidal flat forms because wave erosion constantly wipes out incisions caused by tidal fluxes. For intermediate conditions, a new stable state is present with a tidal flat dissected by channels. Waves maintain the tidal flat below mean sea level while tides scour the channels and keep them flushed. The system can therefore shift among these three stable states (a marsh with channels, a tidal flat with channels, and a tidal flat without channels) depending on sediment availability, sea level rise, and the relative strength of wind waves with respect to tidal currents (Mariotti and Fagherazzi, 2013).

\section{Oyster Reef/Mudflat}

Oyster reefs form on hard substrate where the sedimentary environment is often composed of fine particles that are transported as bed load or suspended load by variable flow conditions that result in both suspension and deposition of particles (Papanicolaou et al., 2001; Nestlerode et al., 2007). If the sedimentation rate is too great, oyster larvae, as well as juvenile and adult oysters, can be buried, preventing the transition back to oyster reef habitat (Mackenzie, 1983). Sedimentation rates are typically highest along the low-lying bases of reefs where oyster and oyster larvae mortality is greatest (Lenihan, 1999). However, once established, the vertical accretion of living oyster reef structure can prevent burial and enhance the expansion of area suitable for larval settlement, making reef structures optimal locations for recruitment and expansion of oyster populations. Like many other bivalve larvae, oyster larvae determine proper settlement sites depending upon local hydrodynamics and chemical cues (Fredriksson et al., 2010; Koehl and Hadfield, 2010). After contacting the bed, if they find their first landing site to be unsuitable, larvae can release themselves back into the flow and test the next site (Soniat et al., 2004; Fuchs et al., 2007).

For many coastal regions that could sustain large oyster populations, once a transition to mudflat occurs, there is limited benthic habitat that is suitable for larval settlement and growth (Whitman and Reidenbach, 2012). One way to circumvent this problem is to add hard substrate (such as oyster shell) to facilitate natural recruitment processes (Coen and Luckenbach, 2000). Recent restoration successes have occurred in sanctuary areas where higher vertical relief of the benthic substrate increases recruitment and growth of oysters (Schulte et al., 2009). In the VCR, the greatest larval recruitment in restoration sites occurred in regions of high elevation with respect to mean water level and of large topographic roughness that prevented burial by sediment and provided refuge from predation (Whitman and Reidenbach, 2012). Factors such as local hydrodynamics, benthic topography, and location on the reef with respect to the mean water surface all play an important role in oyster survival (Bartol and Mann, 1997; 
Lenihan, 1999) and in controlling alternative stable state transitions between mudflat and oyster reef habitats.

\section{COUPLING OF}

\section{ADJACENT SYSTEMS}

\section{Seagrass and Marsh}

Our understanding of the mechanisms promoting the existence of salt marshes and tidal flats as alternative states does not account for the role of seagrasses and their effects on waves, bed scouring, and sediment resuspension. These effects influence the wave energy impacting the adjacent marsh boundary and the sediment supply for marsh accretion in response to sea level rise (Figure 5).

Vegetation strongly affects the dynamics of the coupled tidal flat-salt marsh system. Belowground root/ rhizome production and the effects of the leaf canopy in promoting sediment accretion allow the marsh to keep pace with sea level rise (Kirwan and Murray, 2007; Kirwan et al., 2010). Likewise, because seagrass meadows enhance deposition of fine particles and reduce sediment resuspension (Koch et al., 2006; Gruber and Kemp, 2010; Hansen and Reidenbach, 2012), their presence likely diminishes the volume of sediment that can be exported from subtidal zones to salt marshes at high tide.

Seagrass meadows also influence the shallow-water wave environment in ways that affect marsh-edge erosion. Waves play a major role in controlling erosion along marsh boundaries (van der Wal and Pye, 2004; Mariotti et al., 2010; Tonelli et al., 2010), although other factors such as edge morphology, sediment grain size, vegetation characteristics, and the abundance of bivalves and burrowing crabs are also important (Phillips, 1986; Feagin et al., 2009; recent work of Sean
McLaughlin, University of Virginia, and colleagues). Seagrass meadows attenuate wave energy, and this process likely reduces erosion of adjacent marsh edges. Seagrass meadows also indirectly affect the wave environment by increasing seafloor elevation through enhanced deposition. Because wave height decreases with shallower water depths (Fagherazzi et al., 2006), the presence of seagrass would decrease bed scour and sediment resuspension by wave action. Moreover, seagrass meadows modify the hydrodynamics of nearby bare sediment areas, influencing a larger area than what they occupy (Folkard, 2011).

Rates of marsh-edge erosion have been observed in many coastal environments, ranging from $\sim 0.1$ to $>3 \mathrm{~m}$ per year (e.g., Day et al., 1998; Schwimmer, 2001; Wilson and Allison, 2008; recent work of Sean McLaughlin, University of Virginia, and colleagues). One key question is: what is the fate of this eroded sediment? If sediment eroded from the marsh edges feeds deposition on the

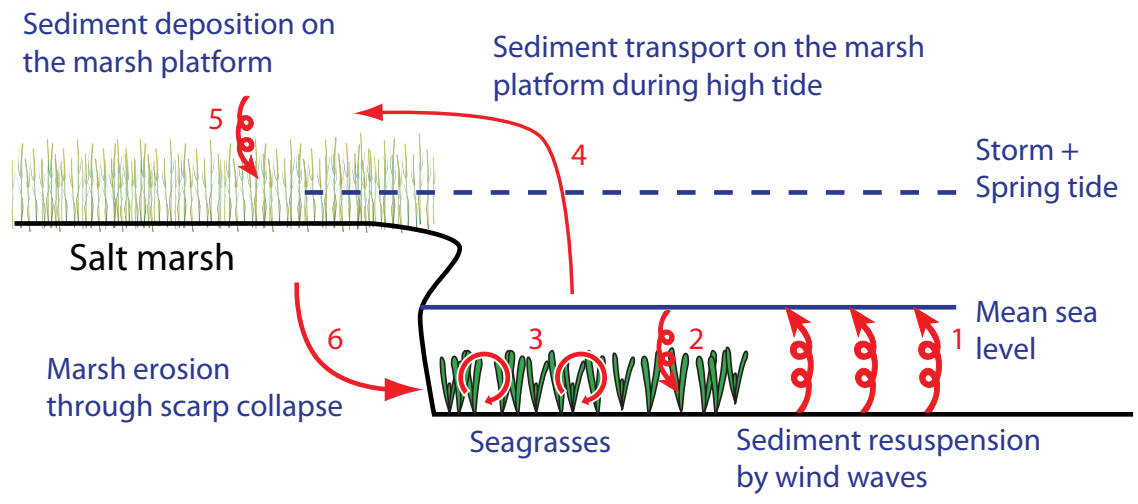

Tidal flat

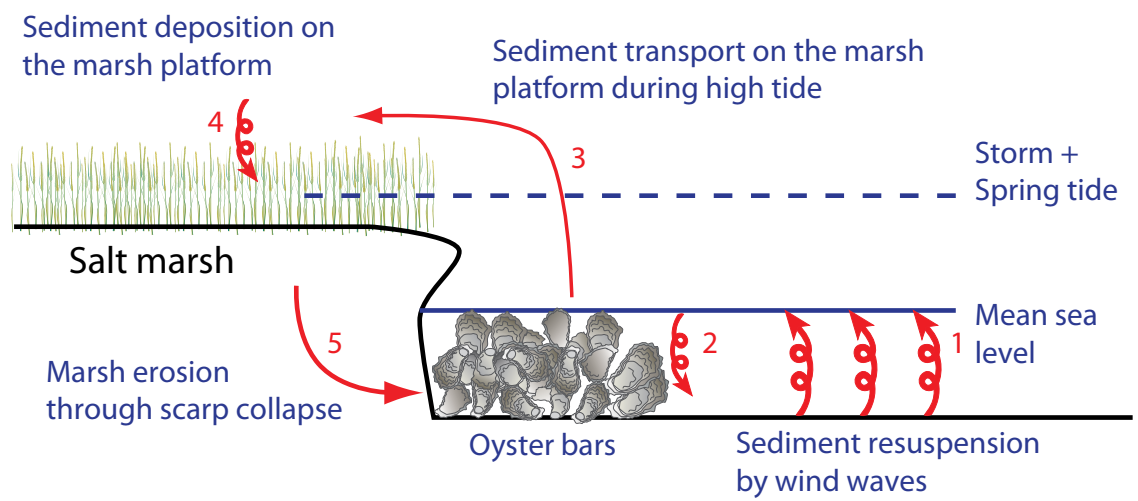

Tidal flat

Figure 5. The coupled evolution of subtidal and intertidal habitats influences the nonlinear dynamics of both in response to long-term drivers of change. Seagrass meadows and intertidal oyster reefs adjacent to intertidal marshes attenuate wave energy that impacts the adjacent marsh boundary, affecting erosion rates and also the supply of sediments for marsh accretion in response to sea level rise. Sediment eroded from marsh edges may negatively influence light availability for seagrass growth. The upper panel shows that seagrass meadows promote sedimentation (arrow \#2) and reduce sediment resuspension (arrow \#3) compared to unvegetated areas (arrow \#1). Likewise, oyster reefs promote particle settlement by filtering the water column (lower panel, arrow \#2). 
marsh surfaces, then increases in erosion rate related to sea level rise and storm frequency (Mariotti et al., 2010) may supply some of the sediment needed for the marshes to increase their elevation to keep pace with sea level rise. On the other hand, if sediment eroded from the marsh edges is transported into the bays rather than onto the marsh platforms, does this have a negative feedback on light attenuation in the water column and the growth conditions for seagrass? Only a comprehensive research approach that includes seagrasses in the coupled evolution of salt marshes and tidal flats will shed light on the critical feedbacks between subtidal and intertidal ecosystem dynamics.

\section{Oyster Reef and Marsh}

Similar to seagrass beds, oyster reefs adjacent to intertidal marshes can impact marsh-edge erosion and vertical accretion by reducing sediment availability and dissipating wave energy (Figure 5). Through active filtration of water masses, oysters remove sediment, microalgae, and other particles and, in doing so, improve water clarity and impact local sedimentation processes (Dame et al., 1984; Newell, 1988; McCormick-Ray, 1998; Nelson et al., 2004). Efforts to mitigate shoreline loss using "living shorelines" consider oyster reefs as biogenic breakwaters that in some cases reduce shoreline retreat by as much as $40 \%$ (Scyphers et al., 2011). In the VCR LTER, restored oyster reefs have a nonlinear effect on sediment availability for marsh accretion that is related to local energetics of the flow environment. At low to intermediate water velocities ( 0 to $15 \mathrm{~cm} \mathrm{~s}^{-1}$ ), increased sediment uptake by reefs is positively correlated with increasing water velocity due to enhanced turbulent mixing, which makes more of the water column available for filtration. At high velocities ( $>25 \mathrm{~cm} \mathrm{~s}^{-1}$ ), flow-controlled sediment suspension is greater than that of uptake by bivalve filtration, resulting in an efflux and net transport of sediment from the reef.

In waters with high anthropogenic nutrient inputs, this tight coupling between the water column and oyster reefs can also be ecologically beneficial by enhancing denitrification, by increasing bottom-water dissolved oxygen in deeper systems such as the Chesapeake Bay, and by functioning as a bio-filter for nutrients that would otherwise support high phyotoplankton concentrations (Zhou et al., 2006; Cerco and Noel, 2007). A reduction in water column chlorophyll would have a direct benefit on nearby seagrass populations by increasing light availability to the benthos (Cerco and Noel, 2007; McGlathery et al., 2007).

\section{CONCLUSION}

Shallow coastal environments are dynamic systems that are impacted by the combined effects of global (e.g., climate) and local (e.g., land-use) drivers of change. Studies of individual subsystems in the landscape (i.e., marshes, mudflats, oyster reefs, subtidal seagrass meadows, and unvegetated sediments) show that biotic feedbacks lead to nonlinear responses to changing conditions (e.g., sea level rise, storms, sediment and nutrient delivery) and to the emergence of thresholds, hysteresis, and alternative stable states. These rapid state changes-or so-called regime shifts-are a challenge for ecosystem management because they are often difficult to predict or anticipate (Clark et al., 2001), may be beyond the range of historical experience (Carpenter, 2002, 2003), and involve thresholds that are sometimes poorly known (Groffman et al., 2006). Moreover, regime shifts can greatly impact ecosystem services and have consequences for human well-being (Millennium Assessment, 2005). While there are many examples of regime shifts in coastal systems, not all involve the emergence of alternative stable states (Box 1), and we lack a complete understanding of how common nonlinear dynamics are in coastal and nearshore oceanic environments. Field experiments, such as those described here using seagrass and oyster restoration, and long-term data sets from LTER sites (Box 1; Bestelmeyer et al., 2011), can link internal feedbacks to ecosystem state change.

There are several key research challenges to understanding how the coastal landscape will evolve under future conditions of environmental change. First, while we describe here the emergence and resilience of two alternative stable states (bistable states) at different points in the landscape, there may be conditions under which multiple stable states exist. For example, Marani et al. (2013) describe the evolution of multiple equilibria in the intertidal landscape driven by the feedbacks of different plant species and marsh elevation. To date, research on bistable dynamics in intertidal habitats has focused primarily on a single dominant species, Spartina alterniflora. Likewise, studies on bistable dynamics for subtidal systems has focused on a single seagrass species, Zostera marina, that dominates temperate and polar latitudes. It is also possible that mixed species assemblages would lead to multiple equilibria. Oyster reefs could also represent an intermediate stable state between salt marshes and mudflats due to the enhanced biotic feedbacks they create (Marani et al., 2010).

Second, we present here a conceptual framework for understanding the 
coupled evolution of systems within the coastal landscape. Models and experiments are needed to test how the occurrence of a regime shift in one system may propagate to affect adjacent systems. For example, the presence of seagrass meadows and oyster reefs may have a positive (wave attenuation) or a negative (reduced sediment supply) effect on adjacent marshes. Likewise, marsh-edge erosion could negatively influence the light environment for seagrass growth. Third, while early warning indicators of thresholds for rapid state change may exist, for most coastal systems we do not know what these leading indicators are or how to quantify them. Forecasting the resilience of coastal ecosystems and the landscape-scale response to environmental change in the next century requires an understanding of these nonlinear dynamics, their coupled evolution, and potential early warning signs of tipping points for rapid ecosystem state changes.

\section{ACKNOWLEDGEMENTS}

This work was supported by the National Science Foundation, most recently through grants DEB-0621014 and DEB-1237733 to the Virginia Coast Reserve Long Term Ecological Research site. We thank Alan Joyner for drafting Figure 1 and Luke Cole for drafting Figures 3 and 5.

\section{REFERENCES}

Angelini, C., and B.R. Silliman. 2012. Patch sizedependent community recovery after massive disturbance. Ecology 93:101-110, http:// dx.doi.org/10.1890/11-0557.1.

Bartol, I.K., and R. Mann. 1997. Small-scale settlement patterns of the oyster Crassostrea virginica on a constructed intertidal reef. Bulletin of Marine Science 61:881-897.

Bestelmeyer, B.T., A.M. Ellison, W.R. Fraser, K.B. Gorman, S.J. Holbrook, C.M. Laney, M.D. Ohman, D.P.C. Peters, F.C. Pillsbury, A. Rassweiler, and others. 2011. Analysis of abrupt transitions in ecological systems. Ecosphere 2(12):129, http://dx.doi.org/10.1890/ ES11-00216.1.
Biggs, R., S.R. Carpenter, and W.A. Brock. 2009. Turning back from the brink: Detecting an impending regime shift in time to avert it. Proceedings of the National Academy of Sciences of the United States of America 106:826-831, http://dx.doi.org/10.1073/pnas.0811729106.

Briceño, H.O., and J.N. Boyer. 2010. Climatic controls on phytoplankton in a subtropical estuary, Florida Bay, USA. Estuaries and Coasts 33:541-553, http://dx.doi.org/10.1007/ s12237-009-9189-1.

Carpenter, S.R. 2002. Ecological futures: Building an ecology of the long now. Ecology 83:2,069-2,083, http://dx.doi.org/ 10.1890/0012-9658(2002)083[2069:EFBAEO] 2.0.CO;2.

Carpenter, S.R. 2003. Regime Shifts in Lake Ecosystems: Pattern and Variation. Ecology Institute, Oldendorf/Luhe, Germany, 199 pp.

Carpenter, S.R., J.J. Cole, M.L. Pace, R. Batt, W.A. Brock, T. Cline, J. Coloso, J.R. Hodgson, J.F. Kitchell, D.A. Seekell, and others. 2011. Early warnings of regime shifts: A wholeecosystem experiment. Science 332:1,079-1,082, http://dx.doi.org/10.1126/science.1203672.

Carr, J.A., P. D’Odorico, K.J. McGlathery, and P.L. Wiberg. 2010. Stability and bistability of seagrass ecosystems in shallow coastal lagoons: Role of feedbacks with sediment suspension and light availability. Journal of Geophysical Research 115, G03011, http://dx.doi.org/ 10.1029/2009JG001103.

Carr, J.A., P. D’Odorico, K.J. McGlathery, and P.L. Wiberg. 2012a. Stability and resilience of seagrass meadows to seasonal and interannual dynamics and environmental stress. Journal of Geophysical Research 117, G01007, http:// dx.doi.org/10.1029/2011JG001744.

Carr, J.A., P. D’Odorico, K.J. McGlathery, and P.L. Wiberg. 2012b. Modeling the effects of climate change on eelgrass stability and resilience: Future scenarios and leading indicators of collapse. Marine Ecology Progress Series 448:289-301, http://dx.doi.org/10.3354/ meps09556.

Cerco, C.F., and M.R. Noel. 2007. Can oyster restoration reverse cultural eutrophication in Chesapeake Bay? Estuaries and Coasts 30:331-343, http://dx.doi.org/10.1007/ BF02700175.

Clark, J.S., R. Carpenter, M. Barber, S. Collins, A. Dobson, J. Foley, D. Lodge, M. Pascual, R. Pielke Jr., W. Pizer, and others. 2001. Ecological forecasting: An emerging imperative. Science 293:657-660, http://dx.doi.org/10.1126/ science.293.5530.657.

Coen, L.D., and M.W. Luckenbach. 2000. Developing success criteria and goals for evaluating oyster reef restoration: Ecological function or resource exploitation? Ecological Engineering 15:323-343, http://dx.doi.org/ 10.1016/S0925-8574(00)00084-7.

Contamin, R., and A.M. Ellison. 2009. Indicators of regime shifts in ecological systems: What do we need to know and when do we need to know it. Ecological Applications 19:799-816, http:// dx.doi.org/10.1890/08-0109.1.
Dai, L., D. Vorselen, K.S. Korolev, and J. Gore. 2012. Generic indicators for loss of resilience before a tipping point leading to a population collapse. Science 336:1,175-1,177, http:// dx.doi.org/10.1126/science.1219805.

Dakos, V., E. Benincà, E.H. van Nes, C.J.M. Philippart, M. Scheffer, and J. Huisman. 2009. Interannual variability in species composition explained as seasonally entrained chaos. Proceedings of the Royal Society B 276:2,871-2,880, http://dx.doi.org/ 10.1098/rspb.2009.0584.

Dame, R.F., R.G. Zingmark, and E. Haskin. 1984. Oyster reefs as processors of estuarine materials. Journal of Experimental Marine Biology and Ecology 83:239-247, http://dx.doi.org/10.1016/ S0022-0981(84)80003-9.

Day, J.W. Jr., F. Scarton, A. Rismondo, and D. Are. 1998. Rapid deterioration of a salt marsh in Venice Lagoon, Italy. Journal of Coastal Research 14:583-590.

Deegan, L.A., D.S. Johnson, R.S. Warren, B.J. Peterson, J.W. Fleeger, S. Fagherazzi, and W.M. Wolheim. 2012. Coastal eutrophication as a driver of salt marsh loss. Nature 490:389-392, http://dx.doi.org/10.1038/nature11533.

Di Lorenzo, E., and M.D. Ohman. 2013. A doubleintegration hypothesis to explain ocean ecosystem response to climate forcing. Proceedings of the National Academy of Sciences of the United States of America 110: 2,496-2,499, http:// dx.doi.org/10.1073/pnas.1218022110.

Drake, J.M., and B.D. Griffin. 2010. Early warning signals of extinction in deteriorating environments. Nature 467:456-459, http://dx.doi.org/ 10.1038 /nature09389.

Duarte, C.M., D.J. Conley, J. Carstensen, and M. Sanchez-Camacho. 2009. Return to Neverland: Shifting baselines affect eutrophication restoration targets. Estuaries and Coasts 32:29-36, http://dx.doi.org/10.1007/ s12237-008-9111-2.

Fagherazzi, S., L. Carniello, L. D’Alpaos, and A. Defina. 2006. Critical bifurcation of shallow microtidal landforms in tidal flats and salt marshes. Proceedings of the National Academy of Sciences of the United States of America 103:8,337-8,341, http://dx.doi.org/ $10.1073 /$ pnas.0508379103.

Fagherazzi, S., D.M. Fitzgerald, R.W. Fulweiler, P.L. Wiberg, K.J. McGlathery, J.T. Morris, T.J. Tolhurst, L.A. Deegan, and D.S. Johnson. 2012a. Ecogeomorphology of salt marshes. Pp. 182-200 in Treatise on Geomorphology, vol. 12, Ecogeomorphology. D. Butler and C. Hupp, eds, J. Shroder, exec. ed., Elsevier, http://dx.doi.org/10.1016/B978-0-12-3747396.00329-8.

Fagherazzi, S., D.M. Fitzgerald, R.W. Fulweiler, P.L. Wiberg, K.J. McGlathery, J.T. Morris, T.J. Tolhurst, L.A. Deegan, and D.S. Johnson. 2012b. Ecogeomorphology of tidal flats. Pp. 201-220 in Treatise on Geomorphology, vol. 12, Ecogeomorphology. D. Butler and C. Hupp, eds, J. Shroder, exec. ed., Elsevier, http://dx.doi.org/10.1016/B978-0-12-3747396.00403-6. 
Fagherazzi, S., C. Palermo, M.C. Rulli, L. Carniello, and A. Defina. 2007. Wind waves in shallow microtidal basins and the dynamic equilibrium of tidal flats. Journal of Geophysical Research 112, F02024, http://dx.doi.org/ 10.1029/2006JF000572.

Fagherazzi, S., and P.L. Wiberg. 2009. Importance of wind conditions, fetch, and water levels on wave-generated shear stresses in shallow intertidal basins. Journal of Geophysical Research 114, F03022, http://dx.doi.org/ 10.1029/2008JF001139.

Feagin, R.A., S.M. Lozada-Bernard, T.M. Ravens, I. Moller, K.M. Yeager, and A.H. Baird. 2009. Does vegetation prevent wave erosion of salt marsh edges? Proceedings of the National Academy of Sciences of the United States of America 106:10,109-10,113, http://dx.doi.org/ 10.1073/pnas.0901297106.

Folkard, A.M. 2005. Hydrodynamics of model Posidonia oceanica patches in shallow water. Limnology and Oceanography 50:1,592-1,600.

Folkard, A.M. 2011. Flow regimes in gaps within stands of flexible vegetation: Laboratory flume simulations. Environmental Fluid Mechanics 11:289-306, http://dx.doi.org/ 10.1007/s10652-010-9197-5.

Fredriksson, D.W., C.N. Steppe, L. Wallendorf, S. Sweeney, and D. Kriebel. 2010. Biological and hydrodynamic design considerations for vertically oriented oyster grow out structures. Aquaculture Engineering 42:57-69, http:// dx.doi.org/10.1016/j.aquaeng.2009.11.002.

Fuchs, H.L., M.G. Neubert, and L.S. Mullineaux. 2007. Effects of turbulence-mediated larval behavior on larval supply and settlement in tidal currents. Limnology and Oceanography 52:1,156-1,165, http:// dx.doi.org/10.4319/lo.2007.52.3.1156.

Groffman, P.M., J.S. Baron, T. Blett, A.J. Gold, I. Goodman, L.H. Gunderson, B.M. Levinson, M.A. Palmer, H.W. Paerl, G.D. Peterson, and others. 2006. Ecological thresholds: The key to successful environmental management or an important concept with no practical application. Ecosystems 9:1-13, http:// dx.doi.org/10.1007/s10021-003-0142-z.

Gruber, R.K., and W.M. Kemp. 2010. Feedback effects in a coastal canopy forming submersed plant bed. Limnology and Oceanography 55: 2,285-2,298, http:// dx.doi.org/10.4319/lo.2010.55.6.2285.

Hansen, J.C.R., and M.A Reidenbach. 2012. Wave and tidally driven flows within Zostera marina seagrass beds and their impact on sediment suspension. Marine Ecology Progress Series 448:271-287, http://dx.doi.org/10.3354/ meps09225.

Hansen, J.C.R., and M.A. Reidenbach. 2013. Seasonal growth and senescence of a Zostera marina seagrass meadow alters wave-dominated flow and sediment suspension within a coastal bay. Estuaries and Coasts, http:// dx.doi.org/10.1007/s12237-013-9620-5.

Harrold, C., and D.C. Reed. 1985. Food availability, sea-urchin grazing, and kelp forest community structure. Ecology 66:1,160-1,169, http:// dx.doi.org/10.2307/1939168.
Hutchings, J.A. 1996. Spatial and temporal variation in the density of northern cod and a review of hypotheses for the stock's collapse. Canadian Journal of Fisheries and Aquatic Science 53:943-962.

Kemp, W.M., W.R. Boynton, J.E. Adolf, D.F. Boesch, W.C. Boicourt, G. Brush, J.C. Cornwell, T.R. Fisher, P.M. Glibert, J.D. Hagy, and others. 2005. Eutrophication of Chesapeake Bay: Historical trends and ecological interactions. Marine Ecology Progress Series 303:1-29, http://dx.doi.org/10.3354/ meps303001.

Kirwan, M.L., G.R. Guntenspergen, A. D’Alpaos, J.T. Morris, S.M. Mudd, and S. Temmerman. 2010. Limits on the adaptability of coastal marshes to rising sea level. Geophysical Research Letters 37, L2340, http://dx.doi.org/ 10.1029/2010GL045489.

Kirwan, M.L., and A.B. Murray. 2007. A coupled geomorphic and ecological model of tidal marsh evolution. Proceedings of the National Academy of Sciences of the United States of America 104:6,118-6,122, http://dx.doi.org/ 10.1073/pnas.0700958104.

Koch, E.M., J.D. Ackerman, J. Verduin, and M. van Keulen. 2006. Fluid dynamics in seagrass ecology: From molecules to ecosystems. Pp. 193-225 in Seagrass Biology, Ecology and Conservation. A.W.D. Larkum, R.J. Orth, and C. Duarte, eds, Springer.

Koehl, M.A.R., and M.G. Hadfield. 2010. Hydrodynamics of larval settlement from a larva's point of view. Integrative and Comparative Biology 50(4):539-551, http:// dx.doi.org/10.1093/icb/icq101.

Lenihan, H.S. 1999. Physical-biological coupling on oyster reefs: How habitat structure influences individual performance. Ecological Monographs 69:251-275, http://dx.doi.org/ 10.1890/0012-9615(1999)069[0251:PBCOOR] 2.0.CO;2.

Levin, L.A. 2006. Recent progress in understanding larval dispersal: New directions and digressions. Integrated and Comparative Biology 46:282-297, http://dx.doi.org/10.1093/icb/icj024.

Lindegren, M, V. Dakos, J.P. Gröger, A. Gårdmark, G. Kornilova, S.A. Otto, and C. Möllmann. 2012. Early detection of ecosystem regime shifts: A multiple method evaluation for management application. PLoS One 7:e3841, http:// dx.doi.org/10.1371/journal.pone.0038410.

Mackenzie, C. 1983. To increase oyster production in the northeastern United States. Marine Fisheries Review 45:1-22.

Marani, M., A. D’Alpaos, S. Lanzoni, L. Carniello, and A. Rinaldo. 2007. Biologically controlled multiple equilibria of tidal landforms and the fate of the Venice lagoon. Geophysical Research Letters 34, L11402, http://dx.doi.org/ 10.1029/2007GL030178.

Marani, M., A. D’Alpaos, S. Lanzoni, L. Carniello, and A. Rinaldo. 2010. The importance of being coupled: Stable states and catastrophic shifts in tidal biomorphodynamics. Journal of Geophysical Research 115, F04004, http:// dx.doi.org/10.1029/2009JF001600.
Marani, M., C. Da Lio, and A. D’Alpaos. 2013. Vegetation engineers marsh morphology through multiple competing stable states. Proceedings of the National Academy of Sciences of the United States of America, http:// dx.doi.org/10.1073/pnas.1218327110.

Mariotti, G., and S. Fagherazzi. 2012. Modeling the effect of tides and waves on benthic biofilms. Journal of Geophysical Research 117, G04010, http://dx.doi.org/10.1029/2012JG002064.

Mariotti, G., and S. Fagherazzi. 2013. A two-point dynamic model for the coupled evolution of channels and tidal flats. Journal of Geophysical Research Earth Surface, http://dx.doi.org/ 10.1002/jgrf.20070.

Mariotti, G., S. Fagherazzi, P.L. Wiberg, K.J. McGlathery, L. Carniello, and A. Defina. 2010. Influence of storm surges and sea level on shallow tidal basin erosive processes. Journal of Geophysical Research 115, C11012, http:// dx.doi.org/10.1029/2009JC005892.

May, R.M. 1977. Thresholds and breakpoint in ecosystems with multiplicity of stable states. Nature 269:471-477, http://dx.doi.org/ 10.1038/269471a0.

McCormick-Ray, M. 1998. Oyster reefs in 1878 seascape pattern: Winslow revisited. Estuaries and Coasts 21:784-800, http://dx.doi.org/ $10.2307 / 1353281$.

McCormick-Ray, J. 2005. Historical oyster reef connections to Chesapeake Bay: A framework for consideration. Estuarine, Coastal and Shelf Science 64:119-134, http://dx.doi.org/10.1016/ j.ecss.2005.02.011.

McGlathery, K.J., L.K. Reynolds, L.W. Cole, R.J. Orth, and A. Schwarzschild A. 2012. Recovery trajectories during state change from bare sediment to eelgrass dominance. Marine Ecology Progress Series 448:209-221, http:// dx.doi.org/10.3354/meps09574.

McGlathery, K.J., K. Sundback, and I.C. Anderson. 2007. Eutrophication in shallow coastal bays and lagoons: The role of plants in the coastal filter. Marine Ecology Progress Series 348:1-18, http://dx.doi.org/10.3354/meps07132.

Millennium Assessment. 2005. Ecosystems and Human Well-Being: A Manual for Assessment Practitioners. Island Press, Washington, DC, 288 pp.

Morris, J.T., P.V. Sundareshwar, C.T. Nietch, B. Kjerfve, and D.R. Cahoon. 2002. Responses of coastal wetlands to rising sea level. Ecology 83:2,869-2,877, http://dx.doi.org/ 10.1890/0012-9658(2002)083[2869:ROCWTR] 2.0.CO;2.

Nelson, K.A., L.A. Leonard, M.H. Posey, T.D. Alphin, and M.A. Mallin. 2004. Using transplanted oyster (Crassostrea virginica) beds to improve water quality in small tidal creeks: A pilot study. Journal of Experimental and Marine Biological Ecology 298:347-368, http:// dx.doi.org/10.1016/S0022-0981(03)00367-8

Nestlerode, J.A., M.L. Luckenbach, and F.X. O'beirn. 2007. Settlement and survival of the oyster Crassostrea virginica on created oyster reef habitats in Chesapeake Bay. Restoration Ecology 15:273-283, http:// dx.doi.org/10.1111/j.1526-100X.2007.00210.x. 
Newell, R.I.E. 1988. Ecological changes in Chesapeake Bay: Are they the result of over harvesting the american oyster, Crassostrea virginica? Understanding the Estuary: Advances in Chesapeake Bay Research 129:536-546.

Ogburn, M.B., and M. Alber. 2006. An investigation of salt marsh dieback in Georgia using field transplants. Estuaries and Coasts 29:54-62, http://dx.doi.org/10.1007/BF02784698.

Pace, M.L., S.R. Carpenter, R.A. Johnson, and J.T. Kurtzweil. 2013. Zooplankton provide early warnings of a regime shift in a whole lake manipulation. Limnology and Oceanography 58:525-532, http://dx.doi.org/ 10.4319/lo.2013.58.2.0525.

Papanicolaou, A.N., P. Diplas, C.L. Dancey, and M. Balakrishnan. 2001. Surface roughness effects in near-bed turbulence: Implications to sediment entrainment. Journal of Engineering Mechanics 127:211-218, http://dx.doi.org/ 10.1061/(ASCE)0733-9399(2001)127:3(211).

Paterson, D.M. 1989. Short-term changes in the erodability of intertidal cohesive sediments related to the migratory behavior of epipelic diatoms. Limnology and Oceanography 34(1):223-234.

Peterson, C.H. 1984. Does a rigorous criterion for environmental identity preclude the existence of multiple stable points? American Naturalist 124:127-133.

Petraitis, P.S., E.T. Methratta, E.C. Rhile, N.A. Vidarga, and S.R. Dudgeon. 2009. Experimental confirmation of multiple community states in a marine ecosystem. Oecologia 161:139-148, http://dx.doi.org/ 10.1007/s00442-009-1350-9.

Phillips, J.D. 1986. Coastal submergence and marsh fringe erosion. Journal of Coastal Research 2:427-436.

Porter, J.H. 2007. Landscape change data layer for the Virginia Coast Reserve, 1973-2001. Long Term Ecological Research Network, http:// dx.doi.org/10.6073/pasta/9b8531de67842c4f82e 84ab343e6634c.

Rassweiler, A., R.J. Schmitt, and S.J. Holbrook. 2010. Triggers and maintenance of multiple shifts in the state of a natural community. Oecologia 164:489-498, http://dx.doi.org/ 10.1007/s00442-010-1666-5.

Reynolds, L.K., M. Waycott, K.J. McGlathery, R.J. Orth, and J.C. Zieman. 2012. Eelgrass restoration by seed maintains genetic diversity: Case study from a coastal bay system. Marine Ecology Progress Series 448:223-233, http://dx.doi.org/ 10.3354/meps09386.

Rotschild, B.J., J.S. Ault, P. Goulletquer, and M. Heral. 1994. Decline of the Chesapeake Bay oyster population: A century of habitat destruction and overfishing. Marine Ecology Progress Series 111:29-39.

Scheffer, M. 2009. Critical Transitions in Nature and Society. Princeton University Press, Princeton, NJ, $384 \mathrm{pp}$.

Scheffer, M., J. Bascompte, W.A. Brock, V. Brovkin, S.R. Carpenter, V. Dakos, H. Held, E.H. van Nes, M. Rietkerk, and G. Sugihara.
2009. Early warning signals for critical transitions. Nature 461:53-59, http://dx.doi.org/ 10.1038 /nature 08227.

Scheffer, M., S.R. Carpenter, J.A. Foley, C. Folke, and B. Walker. 2001. Catastrophic shifts in ecosystems. Nature 413:591-596, http://dx.doi.org/ 10.1038/35098000.

Schulte, D.M., R.P. Burke, and R.N. Lipcius. 2009. Unprecedented restoration of a native oyster metapopulation. Science 325:1,124-1,128, http://dx.doi.org/10.1126/science.1176516.

Schröder, A., L. Persson, A.M. De Roos. 2005. Direct experimental evidence for alternative stable states: A review. Oikos 110:3-19, http:// dx.doi.org/10.1111/j.0030-1299.2005.13962.x.

Schwimmer, R.A. 2001. Rates and processes of marsh shoreline erosion in Rehoboth Bay, Delaware, USA. Journal of Coastal Research 17:672-683.

Scyphers, S.B., S.P. Powers, K.L. Heck Jr., and D. Byron. 2011. Oyster reefs as natural breakwaters mitigate shoreline loss and facilitate fisheries. PLoS ONE 6(8):e22396, http:// dx.doi.org/10.1371/journal.pone.0022396.

Seekell, D.A., S.R. Carpenter, T.J. Cline, and M.L. Pace. 2012. Conditional heteroskedasticity forecasts regime shift in a whole-ecosystem experiment. Ecosystems 15:751-757, http:// dx.doi.org/10.1007/s10021-012-9542-2.

Soniat, T.M., C.M. Finelli, and J.T. Ruiz. 2004. Vertical structure and predator refuge mediate oyster reef development and community dynamics. Journal of Experimental Marine Biology and Ecology 310:163-182, http:// dx.doi.org/10.1016/j.jembe.2004.04.007.

Steneck, R.S., M.H. Graham, B.J. Bourque, D. Corbet, J.M. Erlandson, J.A. Estes, M.J. Tegner. 2002. Kelp forest ecosystems: Biodiversity, stability, resilience, and future. Environmental Conservation 29:436-459, http:// dx.doi.org/10.1017/S0376892902000322.

Tonelli, M., S. Fagherazzi, and M. Petti. 2010. Modeling wave impact on salt marsh boundaries. Journal of Geophysical Research Oceans 115, C09028, http://dx.doi.org/ 10.1029/2009JC006026.

van der Heide, T., T.J. Bouma, H. Egbert, J. van Nes, J. van de Koppel, M. Scheffer, J.G.M. Roelofs, M.M. van Katwijk, and A.J.P. Smolders. 2010. Spatial self-organized patterning in seagrasses along a depth gradient of an intertidal ecosystem. Ecology 91:362-369, http://dx.doi.org/ 10.1890/08-1567.1.

van der Wal, D., and K. Pye. 2004. Patterns, rates and possible causes of saltmarsh erosion in the Greater Thames area (UK). Geomorphology 61:373-391, http:// dx.doi.org/10.1016/j.geomorph.2004.02.005.

Van Katwijk, M.M., A.R. Bos, V.N. de Jonge, L. Hanssen, D.C.R. Hermus, and D.J. de Jong. 2009. Guidelines for seagrass restoration: Importance of habitat selection and donor population, spreading of risks, and ecosystem engineering effects. Marine Pollution Bulletin 58:179-188, http://dx.doi.org/10.1016/ j.marpolbul.2008.09.028.
Van Nes, E.H., and M. Scheffer. 2007. Slow recovery from perturbations as a generic indicator of nearby catastrophic shift. American Naturalist 170:660.

Veraart, A.J., E.J. Faassen, V. Dakos, E.H. van Nes, M. Lurling, and M. Scheffer. 2012. Recovery rates reflect distance to a tipping point in a living system. Nature 481:357-359, http:// dx.doi.org/10.1038/nature10723.

Verhagen, J.H.G., and P.H. Nienhuis. 1983. A simulation-model of production, seasonal-changes in biomass and distribution of eelgrass (Zostera marina) in lake Grevelingen. Marine Ecology Progress Series 10:187-195.

Wachnicka, A., L.S. Collins, and E.E. Gaiser. 2013. Response of diatom assemblages to 130 years of environmental change in Florida Bay (USA). Journal of Paleolimnology 49:83-101, http:// dx.doi.org/10.1007/s10933-011-9556-3.

Walker, B., and J.A. Meyers. 2004. Thresholds in ecological and social-ecological systems: A developing database. Ecology and Society 9(2):3, http://www.ecologyandsociety.org/vol9/ iss $2 /$ art3

Walker, B.H., and D. Salt. 2006. Resilience Thinking: Sustaining Ecosystems and People in a Changing World. Island Press, Washington, DC, 174 pp.

Weerman, E.J., J.J. van Belzen, M. Rietkirk, S. Temmerman, S. Kefi, P.M.J. Herman, and J. van de Koppel. 2012. Changes in diatom patch-size distribution and degradation in a spatially self-organized intertidal mudflat ecosystem. Ecology 93:608-618, http://dx.doi.org/ 10.1890/11-0625.1.

Whitman, E.R., and M.A. Reidenbach. 2012. Benthic flow environments affect recruitment of Crassostrea virginica larvae to an intertidal oyster reef. Marine Ecology Progress Series 463:177-191, http://dx.doi.org/10.3354/ meps09882.

Wilson, C.A., and M.A. Allison. 2008. An equilibrium profile model for retreating marsh shorelines in southeast Louisiana. Estuarine, Coastal and Shelf Science 80:483-494, http://dx.doi.org/ 10.1016/j.ecss.2008.09.004.

Zharova, N., A. Sfriso, A. Voinov, and B. Pavoni. 2001. A simulation model for the annual fluctuation of Zostera marina biomass in the Venice lagoon. Aquatic Botany 70:135-150, http:// dx.doi.org/10.1016/S0304-3770(01)00151-6.

Zhou, Y., H. Yang, T. Zhang, S. Liu, S. Zhang, Q. Liu, J. Xiang, and F. Zhang. 2006. Influence of filtering and biodeposition by the cultured scallop Chlamys farreri on benthic-pelagic coupling in a eutrophic bay in China. Marine Ecology Progress Series 317:127-141, http:// dx.doi.org/10.3354/meps317127. 